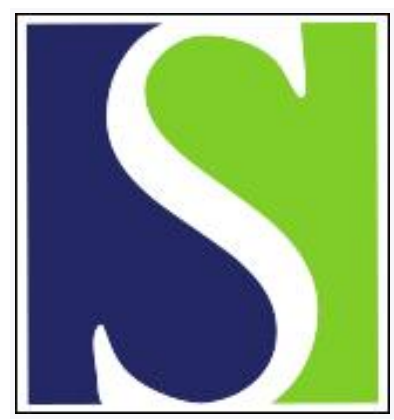

Scand J Work Environ Health 2009;35(5):368-375

https://doi.org/10.5271/sjweh.1328

Published online: 13 May 2009, Issue date: 00 Oct 2009

Respiratory effects in the aftermath of a major fire in a chemical waste depot

by Greven F, Kerstjens HAM, Duijm F, Eppinga P, de Meer G, Heederik D

Affiliation: Department of Environmental Health, Municipal Health Services, Hulpverleningsdienst Groningen, PO Box 584, 9700 AN, Groningen, the Netherlands. f.greven@hvd.groningen.nl

Key terms: airway irritant; chemical fire; chemical waste depot; dose-response slope; fire; histamine challenge testing; persistent respiratory symptom; RADS; Reactive Airways Dysfunction Syndrome; respiratory effect

This article in PubMed: www.ncbi.nlm.nih.gov/pubmed/19436923 


\title{
Respiratory effects in the aftermath of a major fire in a chemical waste depot
}

\author{
by Frans Greven, MSc, ${ }^{1,2}$ Huib AM Kerstjens, PhD, ${ }^{3}$ Frans Duijm, MD, ${ }^{1}$ Pier Eppinga, MD, ${ }^{4}$ Gea de Meer, \\ $P h D,{ }^{5}$ Dick Heederik, $P h D^{2,6}$
}

\author{
Greven F, Kerstjens HAM, Duijm F, Eppinga P, de Meer G, Heederik D. Respiratory effects in the aftermath of a \\ major fire in a chemical waste depot. Scand J Work Environ Health. 2009;35(5):368-375.
}

Objective The aim of this study was to investigate respiratory effects among emergency services first responders and residents exposed to combustion products in the aftermath of a chemical waste depot fire.

Methods The study population comprised 138 individuals who were present in the area downwind of an accidental fire. Identified by telephone interview six years later, subjects with persistent respiratory symptoms were suspected as having Reactive Airways Dysfunction Syndrome (RADS). Medical tests were performed. For bronchial responsiveness, a cut-off point of $\mathrm{PD}_{20}<2.39 \mathrm{mg}$ histamine was taken and a dose-response slope (DRS) was calculated. Suspected RADS cases were compared with healthy controls for exposure to combustion products, lung function, and bronchial responsiveness.

Results The 25 suspected RADS cases were more frequently exposed than the 99 controls; the crude odds ratio for high versus low exposure was 6.5 [95\% confidence interval (95\% CI) 2.4-18.0]. Suspected cases showed a lower ratio of forced expiratory volume in one second to forced vital capacity $(\mathrm{FEV} / \mathrm{FVC} ; \mathrm{P}=0.028)$. Overall, suspected cases had a higher DRS than controls. The difference was significant for males only ( $\mathrm{P}=0.006)$, and non-smoking males $(\mathrm{P}=0.014)$. Highly exposed subjects had a higher $\mathrm{DRS}$ than low exposed subjects $(\mathrm{P}=0.056)$. These differences were significant when restricted to non-smokers $(\mathrm{P}=0.034)$ and males $(\mathrm{P}=0.019)$. Differences between cases and controls were stronger when the population was restricted to current non-smokers.

Conclusions Persistent respiratory symptoms and bronchial responsiveness were associated with exposure to combustion products of a chemical waste depot fire which occurred more than six years earlier. Authorities and emergency services are recommended to take this into consideration when managing incidents in order to limit possible exposure to airway irritants.

Key terms airway irritant; chemical fire; dose-response slope; histamine challenge testing; persistent respiratory symptom; Reactive Airways Dysfunction Syndrome; RADS

On 12 May 2000, 480 metric tons of chemical waste was burnt in an accidental fire at a hazardous waste disposal site containing batteries, acids, bases, and paint. This resulted in major smoke development and combustion products were dispersed over a large area to the west of the provincial town of Drachten, Friesland in the Netherlands. Firefighters, police officers, and others were exposed to combustion products while performing their emergency tasks. Of those involved professionally, only firefighters used protective gear. Residents of the rural community downwind of the fire were exposed to some extent. During subsequent clean-up activities, over a period of a week, workers were exposed to dust and debris. No fatalities were reported.

The Environmental Incident Service of the Dutch National Institute of Public Health and the Environment (RIVM) measured high levels of particulate matter, heavy metals, dioxins, volatile organic compounds, and hydrogen cyanide $(\mathrm{HCN})$ seven hours after the fire began. No structured sampling strategy was followed. Analyses of compounds did not focus on those potentially relevant for acute respiratory health effects.

1 Department of Environmental Health, Municipal Health Services Groningen, Groningen, the Netherlands.

2 Institute for Risk Assessment Sciences, Utrecht University, Utrecht, the Netherlands.

3 Department of Pulmonary Diseases, University Medical Center Groningen, University of Groningen, Groningen, the Netherlands.

4 Department of Pulmonary Diseases, Nij Smellinghe Hospital, Drachten, the Netherlands.

5 Municipal Health Service Fryslân, Leeuwarden, the Netherlands.

6 Julius Center for Health Sciences and Primary Care, University Medical Center Utrecht, Utrecht, the Netherlands.

Correspondence to: Frans Greven MSc, Department of Environmental Health, Municipal Health Services, Hulpverleningsdienst Groningen, PO Box 584, 9700 AN, Groningen, the Netherlands. [E-mail: f.greven@hvd.groningen.nl] 
RIVM did not sample irritant gases, apart from HCN that had exceeded the Dutch threshold limit value (maximum allowable concentration). Air samples 20-30 m downwind of the fire demonstrated $5500 \mu \mathrm{g} / \mathrm{m} 3$ total suspended particulates. These measurements indicated that exposure levels were high at some point in time, but did not allow for an estimation of the exposure of the area's residents and emergency services. Dispersion modeling indicated that, at a distance of $1000 \mathrm{~m}$ (the distance to the nearest residences), the maximum concentrations of compounds would diminish by a factor of about 500 . Therefore, health risks - other than temporal irritation by inhalation of combustion products - were considered unlikely beyond that distance. Direct health effects resulting from the inhalation of smoke in close proximity to the fire were not assessed $(1,2)$.

There is a lot of data on the respiratory effects resulting from exposure to smoke or combustion products of fires and accidents. However, studies have mainly focused on the short- (3-6) and long-term respiratory effects restricted to fire victims (7) or the occupationally exposed, such as firefighters $(7,8)$. One of the few incidents, in which persisting respiratory effects due to exposure to airway irritants has been studied among residents (9) and first responders (10-12), was the 2001 World Trade Center disaster in New York, USA.

Since the Drachten fire, local inhabitants and emergency services professionals have complained of respiratory symptoms to healthcare providers over a period of several years. The symptoms seemed indicative of irritant-induced asthma, a non-immunological asthma phenotype caused by exposure to airway irritants (13) or Reactive Airways Dysfunction Syndrome (RADS) (14). RADS has been defined as non-immunological asthma produced by a single high exposure to airway irritants, characterized by an abrupt onset of symptoms (within 24 hours after exposure) and the presence and persistence of non-specific bronchial hyper-responsiveness. To our knowledge, our study was the first of its kind to investigate whether lung function and bronchial challenge parameters of residents and emergency services first responders were associated with accidental exposure more than six years previously.

\section{Populations study and methods}

\section{Study design}

Combustion products of a fire in a chemical waste depot were dispersed over an area approximately $3 \times 8 \mathrm{~km}$ (figure 1) downwind from the fire. Five years after the incident, health authorities ordered a follow-up study among individuals present in the affected area at the time of the fire. Subjects were invited to participate through a letter addressed to private residences or places of employment, and an announcement was placed in the local media.

After enrolment, the study protocol consisted of two parts: a telephone interview with all eligible persons to register symptom status, followed by a medical examination, including bronchial challenge testing of a selection of the interviewed population.

\section{Health questionnaire}

In March and April of 2006, we interviewed 138 subjects over the telephone. In order to obtain standardized data, we used a health questionnaire, based on the previously validated Dutch version of the European Community Respiratory Health Survey questionnaire (15). We added questions to identify the onset and duration of symptoms, and determine possible exposure during the fire or the following clean-up.

\section{Case definition}

In this study, we classified a subject as a suspected RADS case if he/she met the following criteria in the telephone interview: (i) no pre-existing respiratory symptoms or known pulmonary pathology, (ii) acute respiratory symptoms following the Drachten fire, such

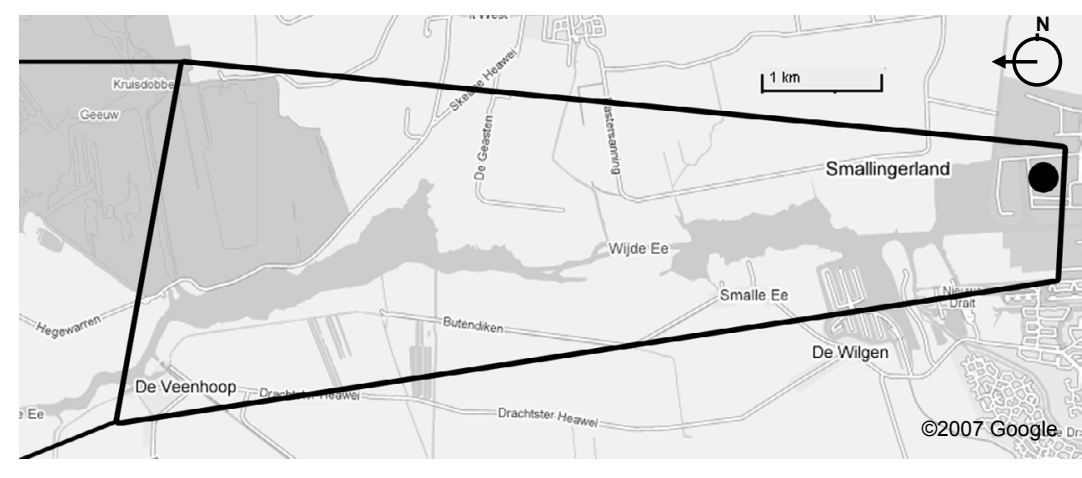

Figure 1. Area approximately $3 \times 8 \mathrm{~km}$ downwind of the fire in a chemical waste depot over which combustion products were dispersed on 12 May 2000. The location of the fire is depicted by a black dot. Wind direction during the fire was eastward. 
as cough, wheezing, and dyspnoea, (iii) recurrence of these symptoms during specified weather conditions or when inhaling irritants or environmental tobacco smoke, and (iv) persistence of these respiratory symptoms for at least three months. We invited all suspected RADS cases to participate in the medical examination. When the examining lung physician could not rule out a diagnosis of current or recovered RADS, a subject was classified as a potential RADS case.

We defined subjects who met the following criteria as controls: (i) no persisting "asthma-like" symptoms for more than three months following the fire and (ii) no pre-existing lung-pathology. Controls were randomly selected for the medical examination in a control to case ratio of $3: 1$. We classified all controls undergoing the medical examinations as examined controls.

\section{Exposure definition}

We defined exposure using different proxies, including: self-reported exposure to combustion products, the date of exposure (the date of the fire or clean-up dates), and the distance to the source. The distance to the source was assessed using a map on which the dispersion of the combustion products was plotted, as well as the location of subjects, using information such as residential addresses, activities during the fire, and the area isolated by police. Exposure was considered: (i) high if a subject reported exposure and had been within $100 \mathrm{~m}$ of the fire, (ii) intermediate if the distance was 100-1000 $\mathrm{m}$, or (iii) low if the distance was $>1 \mathrm{~km}$, if exposure occurred only during clean-up activities, or if there was no self-reported exposure.

\section{Medical examination}

The medical examinations were performed between June 2006 to February 2007 in the Nij Smellinghe Hospital, Drachten, the Netherlands. Subjects visited a lung physician for an interview and physical examination. Venous blood samples were obtained for immunological testing for inhalation allergens (tree and grass pollen, house dust mite, and cat and dog dander) by immunoCAP

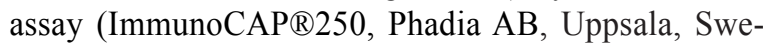
den). Total immunoglobulin E (IgE) was assessed by Immulite assay (Immulite ${ }^{\circledR}$ 2500, Diagnostic Products Corporation, Siemens AG, Germany).

Using European Respiratory Society guidelines (16), lung function testing was conducted on each subject (Masterscreen-PFT, Jaeger/Toennies, Hoechberg, Germany), measuring forced vital capacity (FVC) and forced expiratory volume in one second $\left(\mathrm{FEV}_{1}\right)$. These parameters are presented as \% predicted. In subjects with baseline $\mathrm{FEV}_{1} / \mathrm{FVC}<0.7$ or baseline $\mathrm{FEV}_{1}<85 \%$ predicted, the reversibility of the bronchial obstruction was measured after the inhalation of 400 micrograms salbutamol through a Ventolin ${ }^{\circledR}$ Diskus (GlaxoSmithKline, UK). Significant spirometric bronchodilator response was defined by an absolute increase of $200 \mathrm{ml}$ or an increase of $\mathrm{FEV}_{1} \geq 9 \%$ predicted $(17,18)$.

After receiving written informed consent, we performed histamine challenge testing (HCT) once again using European Respiratory Society guidelines. The subjects inhaled histamine diluted in sterile $0.9 \%$ saline in doubling doses from $0.027-1.493 \mathrm{mg}$. HCT was performed using the 2-minute tidal breathing protocol with histamine delivered via a nebulizer up to a maximum dose of $32 \mathrm{mg} / \mathrm{ml}$ (Master Screen-PFT, analyzer unit, Jaeger) using the Cockroft-criteria (19). We administered increasing doses of histamine until the $\mathrm{FEV}_{1}$ declined by $20 \%$ of baseline $\left(\mathrm{PD}_{20}\right)$ or the maximum cumulative dose of $2.968 \mathrm{mg}$ histamine was reached.

The results of the $\mathrm{HCT}$ were presented using $\mathrm{PD}_{20}$, the calculated dose of histamine that caused the $\mathrm{FEV}_{1}$ to fall by $20 \%$. Bronchial hyper-responsiveness was considered to be present if $\mathrm{PD}_{20} \leq 2.39 \mathrm{mg}$ histamine. To make the best use of the HCT data, we also calculated the dose-response slope [DRS; (20)] as the \% fall in $\mathrm{FEV}_{1}$ per $\mathrm{mg}$ inhaled histamine.

\section{Statistical methods}

We used SPSS versopm 14.0 (SPSS Inc, Chicago, IL, USA) for the statistical analysis. Using logistic regression, we calculated odds ratios between symptoms and exposure variables with confidence intervals. We used the independent-samples T-test to analyze lung function parameters (FVC, $\mathrm{FEV}_{1}$ and $\mathrm{FEV}_{1} / \mathrm{FVC}$ ) and the MannWhitney U-test to non-parametrically analyze DRS. For all tests, P-values $<0.05$ were considered statistically significant.

\section{Results}

\section{Telephone interview}

Population characteristics. The adult population $(\mathrm{N}=138)$ recruited for the study, consisted of $65(47 \%)$ workers involved in the incident, such as police officers and firefighters, and 73 (53\%) employees from neighboring firms, bystanders, and residents present in the potentially exposed area in 2006. The data of $14(10 \%)$ subjects were excluded from the analysis, because they suffered from pre-existing pulmonary pathology or were not present in the catchment area during the incident. Of the remaining 124 interviewed subjects, 25 (18\%) subjects 
Table 1. Population characteristics of cases ${ }^{a}$ and controls $^{b}$ on the basis of the interview.

\begin{tabular}{|c|c|c|c|c|}
\hline & \multicolumn{2}{|c|}{ Case $(\mathrm{N}=25)$} & \multicolumn{2}{|c|}{ Control $(\mathrm{N}=99)$} \\
\hline & $\mathrm{N}$ & $\%$ & $N$ & $\%$ \\
\hline Gender (male) & 19 & 76.0 & 72 & 72.7 \\
\hline \multicolumn{5}{|l|}{ Smoking status } \\
\hline $\begin{array}{l}\text { Current smoker } \\
\text { Former smoker } \\
\text { Never smoked }\end{array}$ & $\begin{array}{r}5 \\
13 \\
7\end{array}$ & $\begin{array}{l}20.0 \\
52.0 \\
28.0\end{array}$ & $\begin{array}{l}19 \\
40 \\
40\end{array}$ & $\begin{array}{l}19.2 \\
40.4 \\
40.4\end{array}$ \\
\hline \multicolumn{5}{|l|}{ Exposure } \\
\hline $\begin{array}{l}\text { Low } \\
\text { Intermediate } \\
\text { High }\end{array}$ & $\begin{array}{r}7 \\
2 \\
16\end{array}$ & $\begin{array}{r}28.0 \\
8.0 \\
64.0\end{array}$ & $\begin{array}{l}63 \\
14 \\
22\end{array}$ & $\begin{array}{l}63.6 \\
14.1 \\
22.2\end{array}$ \\
\hline
\end{tabular}

a Median age 46.7 (SD 9.9, range 28-69) years.

${ }^{b}$ Median age 49.6 (SD 11.0, range 22-72) years.

Table 2. Acute respiratory symptoms ${ }^{\text {a }}$ of suspected cases and controls.

\begin{tabular}{|c|c|c|c|c|c|c|}
\hline \multirow[t]{2}{*}{ Symptoms } & \multicolumn{2}{|c|}{$\begin{array}{l}\text { Cases } \\
(\mathrm{N}=25)\end{array}$} & \multicolumn{2}{|c|}{$\begin{array}{l}\text { Interviewed } \\
\text { control }(N=99)\end{array}$} & \multicolumn{2}{|c|}{$\begin{array}{l}\text { Examined } \\
\text { control }(\mathrm{N}=50)\end{array}$} \\
\hline & $\mathrm{N}$ & $\%$ & $\mathrm{~N}$ & $\%$ & $\mathrm{~N}$ & $\%$ \\
\hline \multicolumn{7}{|l|}{ Cough } \\
\hline Yes & 18 & 72 & 14 & 14 & 7 & 14 \\
\hline No & 3 & 12 & 83 & 84 & 43 & 86 \\
\hline Can’t remember & 4 & 16 & 2 & 2 & 0 & 0 \\
\hline \multicolumn{7}{|l|}{ Wheezing } \\
\hline Yes & 9 & 36 & 3 & 3 & 1 & 2 \\
\hline No & 7 & 28 & 90 & 91 & 46 & 92 \\
\hline Can’t remember & 9 & 36 & 6 & 6 & 3 & 6 \\
\hline \multicolumn{7}{|l|}{ Shortness of breath } \\
\hline Yes & 21 & 84 & 5 & 5 & 1 & 2 \\
\hline No & 3 & 12 & 89 & 90 & 46 & 92 \\
\hline Can’t remember & 1 & 4 & 5 & 5 & 3 & 6 \\
\hline \multicolumn{7}{|l|}{ Dyspnoea } \\
\hline Yes & 13 & 52 & 4 & 4 & 3 & 6 \\
\hline No & 7 & 28 & 90 & 91 & 45 & 90 \\
\hline Can't remember & 5 & 20 & 5 & 5 & 2 & 4 \\
\hline \multicolumn{7}{|l|}{ Chest tightness } \\
\hline Yes & 8 & 32 & 1 & 1 & 0 & 0 \\
\hline No & 8 & 32 & 90 & 91 & 46 & 92 \\
\hline Can’t remember & 9 & 36 & 8 & 8 & 4 & 8 \\
\hline \multicolumn{7}{|l|}{ Runny nose } \\
\hline Yes & 7 & 28 & 4 & 4 & 1 & 2 \\
\hline No & 11 & 44 & 89 & 90 & 46 & 92 \\
\hline Can't remember & 7 & 28 & 6 & 6 & 3 & 6 \\
\hline \multicolumn{7}{|l|}{ Sore throat } \\
\hline Yes & 12 & 48 & 12 & 12 & 3 & 6 \\
\hline No & 8 & 32 & 82 & 83 & 44 & 88 \\
\hline Can't remember & 5 & 20 & 5 & 5 & 3 & 6 \\
\hline \multicolumn{7}{|l|}{ Other symptoms } \\
\hline Yes & 9 & 36 & 9 & 9 & 4 & 8 \\
\hline No & 14 & 56 & 89 & 90 & 46 & 92 \\
\hline Can't remember & 2 & 8 & 1 & 1 & 0 & 0 \\
\hline
\end{tabular}

a Symptoms were considered acute when onset of symptoms was within a week after exposure to the combustion products of the Drachten fire. were classified as suspected cases and $99(72 \%)$ were classified as interviewed controls. General characteristics of the baseline study population are shown in table 1 .

Symptoms. The 25 suspected cases reported having experienced respiratory symptoms shortly after the fire. Table 2 shows the proportions of acute respiratory symptoms in suspected cases, and interviewed and examined controls. Examined controls did not differ from unexamined controls with respect to acute respiratory symptoms.

Associations with exposure. The odds ratios between interview case-control status and exposure were all statistically significantly different from unity (table 3 ). The crude odds ratio for high versus low exposure was 6.5 (95\% CI 2.4-18.0). Associations were stronger when interviewed controls were restricted to those without acute respiratory symptoms and when subjects were restricted to males only. Although the associations weakened when subjects were restricted to current non-smokers and males, the odds ratios remained significant.

\section{Medical examination}

Of the interviewed controls, $75(76 \%)$ were randomly selected to enroll in the medical examination. Because no pathological findings were observed in the first series of examined controls, we considered it unethical to continue evaluating controls. Therefore, we stopped inviting controls after 58 subjects were enrolled. The response rate among invited controls was $86 \%$. The response rate among invited suspected cases was $96 \%$. Responders did not differ from non-responders in terms of age, gender, smoking status, and respiratory symptoms.

Bronchial challenge and spirometry. Suspected cases showed lower average values for $\mathrm{FVC}, \mathrm{FEV}_{1}$ and $\mathrm{FEV}_{1} / \mathrm{FVC}$ in comparison with examined controls (table 4). These differences increased when we restricted the analyses to controls without acute respiratory symptoms following the fire. A similar pattern was observed for potential cases.

The odds ratio between bronchial hyper-responsiveness and case-control status was 1.8 (95\% CI 0.8-5.9). Although this association was stronger when controls were restricted to those without acute respiratory symptoms, this difference was not significant. Controls had a lower DRS than suspected cases, which was significant when the population was restricted to males only ( $\mathrm{P}=0.006)$ and currently non-smoking males $(\mathrm{P}=0.014)$. A similar pattern was seen for potential cases. 
Table 3. Odds ratios (OR) and 95\% confidence intervals (95\% Cl) between case-control status and exposure on the basis of the interview.

\begin{tabular}{|c|c|c|c|c|c|c|c|c|}
\hline & \multicolumn{2}{|c|}{ All } & \multicolumn{2}{|c|}{ Men } & \multicolumn{2}{|c|}{ Non-smokers } & \multicolumn{2}{|c|}{ Non-smoking men } \\
\hline & $\mathrm{OR}$ & $95 \% \mathrm{Cl}$ & OR & $95 \% \mathrm{Cl}$ & $\mathrm{OR}$ & $95 \% \mathrm{Cl}$ & OR & $95 \% \mathrm{Cl}$ \\
\hline High $(\mathrm{N}=38)$ versus low $(\mathrm{N}=70)$ exposure & 6.5 & $2.4-18.0$ & 5.2 & $1.6-16.4$ & 4.6 & $1.6-13.7$ & 3.8 & $1.1-12.8$ \\
\hline Intermediate $(\mathrm{N}=16)$ versus low $(\mathrm{N}=70)$ exposure & 1.3 & $0.2-6.9$ & $<0.1$ & $0.0-35.1^{a}$ & 1.7 & $0.3-9.4$ & $<0.1$ & $0.0-50.4^{a}$ \\
\hline
\end{tabular}

a One of the cells was empty; 0.1 was imputed for the calculations.

Table 4. Lung function parameters and total immunoglobulin $E(\operatorname{lgE})$ results in case-control classes. $\left(F V C=\right.$ forced vital capacity, $F E V_{1}=$ forced expiratory volume in one second, $\mathrm{PD}_{20}=$ the calculated dose of histamine that caused the $\mathrm{FEV}_{1}$ to fall $20 \%$, DRS $=$ dose-response slope calculated as the $\%$ fall in $\mathrm{FEV}_{1}$ per $\mathrm{mg}$ inhaled histamine, $\mathrm{SD}=$ standard deviation)

\begin{tabular}{|c|c|c|c|c|c|c|c|c|c|c|c|c|c|}
\hline & \multicolumn{6}{|c|}{ Predicted } & \multirow{2}{*}{\multicolumn{2}{|c|}{$\mathrm{PD}_{20}$ positive ${ }^{\mathrm{a}}$}} & \multirow{2}{*}{\multicolumn{3}{|c|}{ DRS }} & \multirow{2}{*}{\multicolumn{2}{|c|}{ Total IgE (kU/l) }} \\
\hline & \multicolumn{2}{|c|}{ FVC\% } & \multicolumn{2}{|c|}{$\mathrm{FEV}_{1} \%$} & \multicolumn{2}{|c|}{$\mathrm{FEV}_{1} / \mathrm{FVC} \%$} & & & & & & & \\
\hline & $\begin{array}{c}\text { Geometric } \\
\text { mean }\end{array}$ & SD & $\begin{array}{c}\text { Geometric } \\
\text { mean }\end{array}$ & $S D$ & $\begin{array}{c}\text { Geometric } \\
\text { mean }\end{array}$ & SD & N & $\%$ & Median & $\begin{array}{l}25^{\text {th }} \\
\text { percentile }\end{array}$ & $\begin{array}{c}75^{\text {th }} \\
\text { percentile }\end{array}$ & $\begin{array}{c}\text { Geometric } \\
\text { mean }\end{array}$ & SD \\
\hline Examined control $(\mathrm{N}=50)$ & 108.6 & 13.9 & 104.0 & 18.9 & 95.3 & 11.6 & 11 & 23.9 & 3.6 & 2.1 & 8.3 & 3.4 & 1.3 \\
\hline $\begin{array}{l}\text { Examined control } \\
\text { without acute respiratory } \\
\text { symptoms }(\mathrm{N}=41)\end{array}$ & 108.2 & 14.1 & 105.1 & 18.1 & 96.7 & 10.6 & 7 & 17.1 & 3.5 & 2.0 & 5.8 & 3.3 & 1.3 \\
\hline Suspected case $(\mathrm{N}=24)$ & 107.6 & 11.9 & 101.5 & 14.3 & $94.5^{\mathrm{b}}$ & 8.3 & 6 & 28.6 & $5.9^{c}$ & 3.0 & 17.2 & 3.8 & 1.7 \\
\hline Potential case $(\mathrm{N}=10)$ & 104.0 & 6.6 & $97.4^{\mathrm{d}}$ & 10.8 & 93.6 & 8.3 & 6 & 60.0 & $6.2^{\mathrm{e}}$ & 3.9 & 22.9 & 5.1 & 1.9 \\
\hline
\end{tabular}

a $\mathrm{A}$ positive $\mathrm{PD}_{20}$ (ie, abnormal) was defined as a $\mathrm{PD}_{20} \leq 2.39 \mathrm{mg}$ histamine.

b Significantly different from controls without acute respiratory symptoms, when restricted to current non-smokers ( $P=0.028)$ and currently non-smoking males $(P=0.021)$.

c Significantly different from controls without acute respiratory symptoms, when restricted to males $(P=0.006)$ and currently non-smoking males $(\mathrm{P}=0.014)$.

d Significantly different from controls without acute respiratory symptoms ( $P=0.042)$, when restricted to current non-smokers $(P=0.015)$.

e Significantly different from controls without acute respiratory symptoms $(P=0.004)$.

Associations with exposure. As shown in table 5, highly exposed subjects had lower FVC, $\mathrm{FEV}_{1}$ and $\mathrm{FEV}_{1} / \mathrm{FVC}$ than subjects with low exposure $(\mathrm{P}>0.10)$. The odds ratio between bronchial hyper-responsiveness and exposure was 1.7 (95\% CI 0.5-5.9). Overall, high exposure showed a higher DRS than low exposure $(\mathrm{P}=0.056)$. Associations grew stronger when the population was restricted to males only ( $\mathrm{P}=0.016)$, current non-smokers $(\mathrm{P}=0.034)$, and currently non-smoking males $(\mathrm{P}=0.019)$.

Clinical Investigation. The lung physician ruled out RADS in 14 suspected cases (56\%). In 10 suspected cases (40\%), RADS could not be ruled out.

For three potential cases, we obtained bronchial challenge test data for the years following the fire from other sources. All three cases were smokers at the time of the Drachten fire without pre-existing respiratory complaints. They experienced acute respiratory symptoms which deteriorated during the summer. Independently, they visited a lung physician who performed a histamine or methacholine challenge test (ranging from $\mathrm{PC}_{20}=1.3 \mathrm{~g} / \mathrm{ml}$ histamine to $\mathrm{PC}_{20}=2.5 \mathrm{mg} / \mathrm{ml}$ methacholine). Complaining of newonset respiratory symptoms following the fire, two of the cases visited a physician and quit smoking thereafter. For these individuals, bronchial hyper-responsiveness decreased and respiratory symptoms ameliorated in the following years. In one of these two cases, symptoms were still present in 2006 and bronchial responsiveness was increased $\left(\mathrm{PD}_{20}=0.5671 \mathrm{mg}\right.$ histamine $)$. In the second of the two cases, there were no symptoms in 2006. In the currently smoking case, bronchial hyper-responsiveness was absent in 2006, but respiratory symptoms were still being experienced.

\section{Discussion}

To our knowledge, this was the first study to investigate whether lung function and bronchial challenge parameters of residents and first responders are associated with exposure more than six years previously. In this study, a strong positive association was found between 


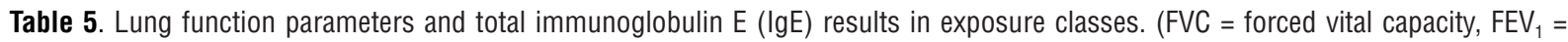
forced expiratory volume in one second, $\mathrm{PD}_{20}=$ the calculated dose of histamine that caused the $F E V_{1}$ to fall $20 \%$, DRS $=$ dose-response slope calculated as the $\%$ fall in $\mathrm{FEV}_{1}$ per mg inhaled histamine)

\begin{tabular}{|c|c|c|c|c|c|c|c|c|c|c|c|c|c|}
\hline \multirow[t]{3}{*}{ Exposure } & \multicolumn{6}{|c|}{ Predicted } & \multirow{2}{*}{\multicolumn{2}{|c|}{$\mathrm{PD}_{20}$ positive ${ }^{\mathrm{a}}$}} & \multirow{2}{*}{\multicolumn{3}{|c|}{ DRS }} & \multirow{2}{*}{\multicolumn{2}{|c|}{ Total IgE (In kU/l) }} \\
\hline & \multicolumn{2}{|c|}{ FVC\% } & \multicolumn{2}{|c|}{$\mathrm{FEV}_{1} \%$} & \multicolumn{2}{|c|}{$\mathrm{FEV}_{1} / \mathrm{FVC} \%$} & & & & & & & \\
\hline & $\begin{array}{c}\text { Geometric } \\
\text { mean }\end{array}$ & SD & $\begin{array}{c}\text { Geometric } \\
\text { mean }\end{array}$ & SD & $\begin{array}{c}\text { Geometric } \\
\text { mean }\end{array}$ & SD & N & $\%$ & Median & $\begin{array}{l}25^{\text {th }} \\
\text { percentile }\end{array}$ & $\begin{array}{l}75^{\text {th }} \\
\text { ercentile }\end{array}$ & $\begin{array}{c}\text { Geometric } \\
\text { mean }\end{array}$ & SD \\
\hline High (N=25) & 106.4 & 10.6 & $100.7^{b}$ & 14.3 & 94.4 & 8.5 & 7 & 28.0 & $4.6^{c}$ & 3.2 & 15.6 & 3.8 & 1.7 \\
\hline Intermediate $(\mathrm{N}=7)$ & 110.0 & 9.4 & 104.2 & 14.3 & 94.6 & 8.8 & 1 & 14.3 & 3.5 & 2.0 & 8.0 & 3.5 & 1.6 \\
\hline Low (N=32) & 110.5 & 13.2 & 107.3 & 15.0 & 97.3 & 8.7 & 6 & 18.7 & 3.4 & 1.6 & 7.0 & 3.2 & 1.2 \\
\hline
\end{tabular}

a $A$ positive $\mathrm{PD}_{20}$ (ie, abnormal) was defined as a $\mathrm{PD}_{20} \leq 2.39 \mathrm{mg}$ histamine.

${ }^{b}$ Borderline significantly different from low exposure $(\mathrm{P}=0.099)$.

c Borderline significantly different from low exposure $(P=0.056)$. Differences become significant when restricted to current non-smokers $(P=0.034)$, males $(\mathrm{P}=0.016)$ and currently non-smoking males $(\mathrm{P}=0.019)$.

exposure to combustion products of a fire in a chemical waste depot and self-reported persisting respiratory symptoms among both workers involved in the incident and the general population in the affected area. These findings were not seriously affected when adjusting for gender, involvement as an emergency services official, or smoking status, all of which mainly resulted in a loss of precision for some odds ratios.

Although no significant differences were found between exposure and $\mathrm{PD}_{20}$, the DRS was significantly lower in low- compared to highly exposed subjects, when restricted to current non-smokers, and males. Suspected cases also showed a lower $\mathrm{FEV}_{1} / \mathrm{FVC}$ and higher DRS than controls. $\mathrm{FEV}_{1}$ was lower in potential cases than in controls. In these cases, the $\mathrm{FEV}_{1} / \mathrm{FVC}$ showed borderline significant differences compared to controls.

The findings of this study are consistent with earlier findings from studies which involved exposure to airway irritants. These findings included persisting respiratory symptoms, spirometric changes, and bronchial hyperresponsiveness in emergency services professionals (10) and residents (9). In some studies, cases with persisting respiratory effects were diagnosed with $\operatorname{RADS}(10,21)$.

Introduced in 1985 by Brooks et al (14), the term RADS is used to describe the development of respiratory symptoms in the minutes or hours after a single accidental inhalation of high concentrations of irritant gases, aerosols, or particles. Later observations have made it clear that RADS can occur after exposure to a great variety of chemicals generated as gases or aerosols, such as sulphuric acid (22), as well as to smoke $(7,14)$ or particles with an irritant nature $(10,23,24)$. Inhalation accidents may occur at home (25), in the workplace $(14,21,26,27)$, or in the general environment $(28,29)$. There is common agreement that RADS is best described as non-immunological occupational asthma without a latency period, occurring after a single exposure to airway irritants and should be distinguished from the more commonly observed occupational asthma, which has in many cases an underlying immunologic mechanism characterized by sensitization (30). Most of the highly exposed subjects emphasized the irritant nature of the combustion products. Given the structure of the questionnaire, cases most likely included newonset cases. None of the interviewed subjects experienced a clinically severe inhalation injury, nor did a considerable part of subjects with persisting respiratory effects in other cohort studies $(10,24,31)$.

The medical evaluation began more than six years after the incident had taken place. To overcome selection bias, we approached the whole population that was present in the affected area at the moment of the fire. To recruit residents, occupationally involved persons, and bystanders, we approached the subjects via a letter to private residences and places of employment, and an announcement in the local media. In the telephone interview, subjects were asked standardized questions about their health and exposure. Cases were selected exclusively on the basis of health criteria. Therefore, selection probability was not related to exposure and health outcome combined (32). The proportion of emergency services professionals and others was evenly distributed over cases and controls. We concluded that self-selection, considering the fact that self-selection always "lies in wait" in this kind of study, undoubtedly played a role. A careful examination of our data indicated that if present, the effects seem to ahve been limited.

In addition, unexamined controls did not differ from the examined controls in terms of age, gender, smoking status, and exposure. Therefore, terminating the invitation of subjects appeared to be a random event, and probably did not affect the associations we found, with the exception that it reduced the statistical power of the study.

The possibility of recall bias is another issue in case-control studies which can result in exposure 
misclassification. This could have played a role in our study because suspected cases could have recalled the onset of their symptoms as very shortly after the fire, when in fact the onset occurred later, or they could have remembered higher than actual exposure. Perception of what happened during and immediately after the incident, and the attribution of symptoms to the incident may have played a role. Some of the subjects could not accurately recall which respiratory symptoms they had experienced, or for how long these symptoms had persisted. This could have resulted in an overestimation of affected associations. On the other hand, controls who were free of symptoms during the study could have forgotten that they had experienced persisting respiratory symptoms, or they could have become so accustomed to their symptoms that they had become insignificant and, therefore, not worth mentioning. It therefore remained difficult to establish how these potential biases affected the associations.

Although high exposure consistently showed more bronchial hyper-responsiveness, only significant associations with exposure were found for DRS. We used DRS as a continuous measure of non-specific airway responsiveness in order to avoid information loss as the HCT data of all subjects could be used. Using bronchial hyper-responsiveness as a measure would have restricted the data source to the subjects with a demonstrated $\mathrm{PD}_{20}$.

Improvements over time usually reduce differences between cases and controls, and between highly and less-exposed subjects. The observation that some associations were still detectable after six years indicated that the respiratory effects were possibly more severe shortly following the Drachten fire. This indication was supported by the observed improvements of the three aforementioned subjects and is consistent with other studies (33).

Despite some uncertainties, we believe that we have found some intriguing associations, which have implications for disaster management. In the major disasters in the Netherlands, such as the Bijlmer disaster and the Enschede fireworks incident, major fires were involved and large, costly studies were undertaken. However, irritant-induced asthma and RADS were not considered as potentially relevant endpoints. RADS and related respiratory effects were considered and demonstrated in the aftermath of the 9/11 disaster in New York (9-12).

An increased awareness amongst emergency services of these respiratory effects may help to avoid unnecessary exposure of those first on the scene and the general population present in the area at the time of an incident. We therefore recommend that authorities consider the respiratory effects of incidents in which exposure to airway irritants is possible.

\section{Acknowledgements}

The authors wish to thank Lisbeth Hall (the National Institute of Public Health and the Environment) for her critical review of the manuscript and John Janssen (Municipal Health Service Fryslân) for his contribution in this study. This study was supported in part by grant for project number 7135.0005 from the Netherlands Organisation for Health Research and Development (ZonMW, The Hague).

\section{References}

1. Mennen MG, van Belle NJC. Emissies van schadelijke stoffen bij branden [Emissions of hazardous compounds from fires]. Bilthoven (Netherlands): RIVM (National Institute for Public Health and the Environment); 2007.

2. van Bruggen M, Baars AJ, Traag WA. Onderzoek naar de gezondheidsrisico's van de emissies van de brand bij ATF in Drachten [Health risks due to emissions from the fire at a waste disposal site in The Netherlands]. Bilthoven (Netherlands):RIVM (National Institute for Public Health and the Environment); 2001.

3. Chia KS, Jeyaratnam J, Chan TB, Lim TK. Airway responsiveness of firefighters after smoke exposure. Br J Ind Med. 1990;47:524-7,

4. Moore D, Copes R, Fisk R, Joy R, Chan K, Brauer M. Population health effects of air quality changes due to forest fires in British Columbia in 2003: estimates from physicianvisit billing data. Can J Public Health. 2006;97:105-8.

5. Shusterman D, Kaplan JZ, Canabarro C. Immediate health effects of an urban wildfire. West J Med. 1993;158:133-8.

6. Upshur R, James ML, Richardson E, Brunton G, Hunter W, Chambers L. Short-term adverse health effects in a community exposed to a large polyvinylchloride plastics fire. Arch Environ Health. 2001;56:264-70.

7. Moisan TC. Prolonged asthma after smoke inhalation: a report of three cases and a review of previous reports. J Occup Med. 1991;33:458-61.

8. Liu D, Tager IB, Balmes JR, Harrison RJ. The effect of smoke inhalation on lung function and airway responsiveness in wildland fire fighters. Am Rev Respir Dis. 1992;146:1469-73.

9. Reibman J, Lin S, Hwang SA, Gulati M, Bowers JA, Rogers L, et al. The World Trade Center residents' respiratory health study: new-onset respiratory symptoms and pulmonary function. Environ Health Perspect. 2005;113:406-11.

10. Banauch GI, Alleyne D, Sanchez R, Olender K, Cohen HW, Weiden M, et al. Persistent hyperreactivity and reactive airway dysfunction in firefighters at the World Trade Center. Am J Respir Crit Care Med. 2003;168:54-62.

11. Banauch GI, Dhala A, Prezant DJ. Pulmonary disease in rescue 
workers at the World Trade Center site. Curr Opin Pulm Med. $2005 ; 11: 160-8$.

12. Prezant DJ, Weiden M, Banauch GI, McGuinness G, Rom WN, Aldrich TK, et al. Cough and bronchial responsiveness in firefighters at the World Trade Center site. N Engl J Med. 2002;347:806-15.

13. Lemiere C, Malo JL, Gautrin D. Nonsensitizing causes of occupational asthma. Med Clin North Am. 1996;80:749-74.

14. Brooks SM, Weiss MA, Bernstein IL. Reactive airways dysfunction syndrome (RADS): persistent asthma syndrome after high level irritant exposures. Chest. 1985;88:376-84.

15. Kerkhof M, de GA, Droste JHJ, Cardynaals RLLM, de Monchy JG, Rijcken B: Prevalentie van astmatische klachten in drie regio's in Nederland [Prevalence of asthma symptoms in three regions in the Netherlands]. Tijdschr Soc Gezondheidsz.1994;72:181-5.

16. Pellegrino R, Viegi G, Brusasco V, Crapo RO, Burgos F, Casaburi $\mathrm{R}$, et al. Interpretative strategies for lung function tests. Eur Respir J. 2005;26:948-68.

17. Calverley PM, Burge PS, Spencer S, Anderson JA, Jones PW. Bronchodilator reversibility testing in chronic obstructive pulmonary disease. Thorax. 2003;58:659-64.

18. Quanjer PH, Tammeling GJ, Cotes JE, Pedersen OF, Peslin $\mathrm{R}$, Yernault JC. Lung volumes and forced ventilatory flows: Report Working Party Standardization of Lung Function Tests, European Community for Steel and Coal: official statement of the European Respiratory Society. Eur Respir J Suppl. 1993;16:5-40.

19. Sterk PJ, Fabbri LM, Quanjer PhH, et al. Airway responsiveness. Standardized challenge testing with pharmacological, physical and sensitizing stimuli in adults. Report Working Party Standardization of Lung Function Tests. European Community for Steel and Coal. Official position of the European Respiratory Society. Eur Respir J. 1993; 6: Suppl. 16, 53-83.

20. O'Connor G, Sparrow D, Taylor D, Segal M, Weiss S. Analysis of dose-response curves to methacholine. An approach suitable for population studies. Am Rev Respir Dis. 1987;136:1412-7.

21. Lemiere C, Malo JL, Boutet M. Reactive airways dysfunction syndrome due to chlorine: sequential bronchial biopsies and functional assessment. Eur Respir J. 1997;10:241-4.
22. Boulet LP. Increases in airway responsiveness following acute exposure to respiratory irritants: reactive airway dysfunction syndrome or occupational asthma? Chest. 1988;94:476-81.

23. Alberts WM, do Pico GA. Reactive airways dysfunction syndrome. Chest. 1996;109:1618-26.

24. Lioy PJ, Weisel CP, Millette JR, Eisenreich S, Vallero D, Offenberg J, et al. Characterization of the dust/smoke aerosol that settled east of the World Trade Center (WTC) in lower Manhattan after the collapse of the WTC 11 September 2001. Environ Health Perspect. 2002;110:703-14.

25. Mrvos R, Dean BS, Krenzelok EP. Home exposures to chlorine/chloramine gas: review of 216 cases. South Med J. 1993;86:654-7.

26. Kern DG. Outbreak of the reactive airways dysfunction syndrome after a spill of glacial acetic acid. Am Rev Respir Dis. 1991;144:1058-64.

27. Stanbury M, Gatti E, Sokolowski JW. Reactive airways dysfunction syndrome in a nurse exposed to pentamidine. J Occup Environ Med. 1996;38:330-1.

28. Cone JE, Wugofski L, Balmes JR, Das R, Bowler R, Alexeeff $\mathrm{G}$, et al. Persistent respiratory health effects after a metam sodium pesticide spill. Chest. 1994;106:500-8.

29. Promisloff RA, Lenchner GS, Phan A, Cichelli AV. Reactive airway dysfunction syndrome in three police officers following a roadside chemical spill. Chest. 1990;98:928-9.

30. Gautrin D, Bernstein IL, Brooks SM, Henneberger PK. Reactive airways dysfunction syndrome and irritant-induced asthma. In: Bernstein IL, Chan-Yeung M, Malo JL, Bernstein DI, editors. Asthma in the workplace. 3 ed. New York (NY): Taylor \& Francis Group; 2006. p 581-629.

31. Nemery B. Reactive fallout of World Trade Center dust. Am J Respir Crit Care Med. 2003;168:2-3.

32. Pearce N, Checkoway H, Kriebel D. Bias in occupational epidemiology studies. Occup Environ Med. 2007;64:562-8.

33. Demeter SL, Cordasco EM, Guidotti TL. Permanent respiratory impairment and upper airway symptoms despite clinical improvement in patients with reactive airways dysfunction syndrome. Sci Total Environ. 2001;270:49-55.

Received for publication: 1 September 2008 